\title{
Controlling as a Method of Managing Human Capital
}

\author{
Michą ZuBEK \\ Institute of Human Capital, Collegium of Business Administration, \\ SGH Warsaw School of Economics
}

\begin{abstract}
Controlling-based management is generally regarded as a way of increasing the operational efficiency of economic entities. Considering controlling based on the management level criterion makes it easier to control an organisation's revenues and costs, whose greatest source are labour costs. In the knowledge- and IT-based economy, information processing and corporate social responsibility (CSR), being the outcome of evolution from the industry-based economy, have dominated management processes.
\end{abstract}

Keywords: human capital, personnel management, methods of managing, Human Resource analytics

JEL Classification Code: M120 


\section{Introduction}

In each organisation, the capital carried by human resources constitutes the basis for all capitals involved, i.e. material, financial, and human capital, as well as social capital, added to this list in the late $20^{\text {th }}$ century by R. Putman and F. Fukuyama. Human capital provides the basis for the other capitals, without it they are deprived of the potential for development. It is the core that makes up, builds and integrates the other capitals, making them useful and essential to any organisational thought and management practice (Czapiński, 2008). The presence of human capital is the conditio sine quo non for following any method of managing an organisation as a whole, as well as all the elements of which it is made up, especially in the controlling-based approach to management.

Controlling-based management is generally regarded as a way of increasing the operational efficiency of economic entities. In highly developed countries, it has proved to be an effective method for counteracting crisis, risks, competition, and the increasing changeability of the environment. For Polish enterprises, in turn, it has become a management style that prevents insolvency and ensures long-term development (Ignaciuk. 2000, p. 25).

The approach to controlling based on the management level criterion makes it easier to control costs and revenues, however, the result management process must include the observation of the degree of fulfilment of selected functions, e.g. the personnel function (Sierpińska, 2004, p. 9). As a matter of fact, labour costs are the dominant item in all types of organisations and as such, they should be particularly interesting to each and every area of an organisation's activity. However, human capital is the source of the highest costs, and thus it can be the source of the 'power' or the 'powerlessness' of an organisation, manifesting itself in its effective operation. Managing employees is so important because the economic results of a company depend directly on their knowledge, skills, and work ethos. While good and competent personnel, both at the management and implementation level, are able to get even a badly-doing company 'back on its feet', it is also possible that a company equipped with the best technology, embodied in state-of-the-art devices, will not survive on the market if it has incompetent management and badly managed employees.

The author raises a research question of whether it is justified for Polish organisations to use controlling-based management of human capital in the context of costs incurred by companies and results they have achieved. 


\section{Conditions for human capital management processes in an organisation}

Personnel controlling is functional controlling concerning the human resources function and maintaining the basic defining characteristics of the idea layer of controlling in its broadest sense, i.e. it is oriented towards the effectiveness of managing the existing human resources, and in addition to formulating rules and procedures for planning, organising, coordinating, directing, and controlling in the area of human resources, it also performs motivational functions. With properly functioning personnel controlling, it is possible to identify bottlenecks and eliminate them relatively quickly (Nowak, 2008, p. 16). The most common bottlenecks in personnel policy include staff shortages, inadequate employee competences, fluctuation and absenteeism, excessive absorption, personnel dispersion, excessive concentrations of human capital in proportions inadequate at a given time, and lack of motivation.

Dynamic changes in the environment, threats to the existence and operation of enterprises, improper exploitation of non-renewable resources, and the knowledgebased economy necessitate changes in our perception of reality and the use of ultramodern solutions, especially in the area of the personnel function. This requires not only a structural reorganisation, but also a change in the current ways of thinking and the current mentality and the introduction of rules adequate to changes in the development situation of a company, free of archaisms and stereotypes. Such eliminated habits and outdated solutions should be replaced with attitudes and solutions rich in future-oriented, broad-minded thinking, open to the new, aware of the meaning and importance of organisational culture for systematic growth, capable of understanding the new economy. Unfortunately, although many examples of such 'resourcefulness' have emerged in the world, in some regions of Poland substantial deficiencies can be noticed in these areas, both on the part of enterprise owners and managers as well as persons managing public sector institutions and organisations.

A factor that affects negatively the effectiveness of human capital management in Poland is the lack of retention mechanisms. This leads to a very dangerous phenomenon of human capital dispersion, both on the national and regional level. While emigration is a legally sanctioned phenomenon, as every person has the right to freedom of movement and residence within the borders of each state (Article 13(1) of the Universal Declaration of Human Rights), it causes further impoverishment of poor regions, and in extreme cases, it actually deprives them of that most valuable resource - human resources. If the population decreases, regardless of the factors responsible for this phenomenon, the income of that region drops, which causes 
a decline in the living standards of its inhabitants. In many cases, this situation causes people to take personal decisions on emigration in search of better living and working conditions. However, decisions on moving within the border of a state do disrupt the national labour market at the national scale, the supply and demand relations for labour force remain relatively proper, if we assume that human capital management takes into account internal migration phenomena.

In the absence of actions to prevent leaving the country, the observed loss of human resources and the potential that they carry (educated doctors, engineers, experts and specialists in various fields), the following conclusions can be drawn:

- increased migration causes a decrease in a given region's wealth;

- appearance of poverty which, irrespective of the migration type (resulting from expatriation or other factors), always inhibits and delays economic and social development;

- dysfunctions emerging with the micro-scale transfer to the macro-scale, which, in future, has negative and irreversible effects preventing the sustainable development of particular regions and the entire country.

Sustainable development refers to social and economic development of modern societies that consists in meeting their needs without compromising the ability of future generations to meet their own needs. The term 'sustainable development' was defined and introduced in 1987 by G. Brudtland in the report of the World Commission on Environment and Development entitled Our Common Future. The concept of sustainable development is defined more precisely by two documents adopted at the 1992 UN Conference on Environment and Development in Rio de Janeiro (Encyklopedia PWN).

In Poland, the principle of sustainable development has been given constitutional status: it is incorporated in Article 5 of the Constitution of the Republic of Poland. It was defined as

...such socio-economic development which integrates political, economic and social actions while preserving the natural equilibrium and the sustainability of basic natural processes, with the aim of guaranteeing the ability of individual communities or citizens, of both the present and future generations, to satisfy their basic needs (the Environment Protection Law Act of 27 April 2001).

In practice, 'sustainable development' is used as a synonym for 'pro-ecological' behaviours, and in business environments it is equated with success and innovativeness, or, in fact, corporate social responsibility (CSR). The first references to corporate responsibility were recorded in 1916 (Champlin \& Knoedler, 2004). According to the definition of the European Commission, CSR is the responsibility of enterprises for their impacts on society. 
Corporate Social Responsibility (CSR) is the result of the evolution from the industry-based economy, in which a technocratic approach to economic growth was dominant, to the modern, multidisciplinary, humanitarian concept contained in the Universal Declaration of Human Rights, ${ }^{1}$ which was adopted and proclaimed as UN General Assembly resolution 217A (III) on 10 December 1948. According to its rules:

a human being is an entity and has a number of rights, especially the right to a healthy and productive life in harmony with nature, the well-being of human beings worldwide, intergenerational justice, and personal fulfilment of the individual.

All types of private and public organisations from all sectors, including the government, local government, and non-governmental organisations, functioning in various areas and spheres of life, must have regard to the issues discussed above when employing people.

Additionally, due to the modern technological progress that determines the development of the 'knowledge-based' economy, human resources management requires taking into account the new order defined as the information processing/ knowledge management era.' In the 1970s and 1980s, the 'knowledge management era' was referred to as the cybernetic age, the electronic epoch, or the information era (McLuhan, 1975, p. 135). At present, nobody wonders if IT systems are necessary for wide application in processes supporting human resources management; instead, solutions are sought that would enable artificial intelligence systems to reach all participants of the economic and social life. The implementation of new IT and ICT systems in a modern enterprise, irrespective of its size or industry, is a necessity, and this requires synchronising the activities of the human resources management team and the IT team.

1 The Universal Declaration of Human Rights is the most frequently translated document in the world (it has been translated into more than 500 languages). The Declaration inspired over 80 international treaties and declarations concerning human rights, numerous regional documents, and acts of national law. Based on the Universal Declaration of Human Rights, the International Covenant on Civil and Political Rights and the International Covenant on Economic, Social and Cultural Rights entered into force in 1976. Together with the Universal Declaration of Human Rights, these covenants make up the International Bill of Human Rights. By now, all the UN Member States have ratified at least 1 of the 9 basic international treaties concerning human rights, and $80 \%$ have ratified 4 or more of such treaties. This confirms the universality of the Universal Declaration of Human Rights. 


\section{Methods for managing human resources and instruments used by HR managers}

Due to its unquestionable role in treating an organisation as a whole, personnel controlling focuses not only on the personnel strategy, but also on interactions between the personnel strategy and other strategies of a given organisation. Such a comprehensive approach makes it possible to take the right management decisions at the stage of planning the company's objectives and organisational processes, coordinating activities, and controlling the outcomes.

In Poland, a growing interest in the new approach to human resources management processes has been observed since the early 1980s. Owners of companies and institutions and their managers are noticing that personnel controlling may be an important element in the strategic approach to the management of a modern organisation. Apart from its ideological layer, controlling has a rich pragmatic layer encompassing a wide range of methods, tools, and instruments necessary to achieve the main objective, which is to make the personnel function of an organisation better and more efficient (Listwan, 2010, p. 59).

Despite the fact that Polish entrepreneurs notice the advantages coming from controlling-based human capital management, the application of controlling encounters difficulties, especially in companies having Polish roots. The logical structure of barriers to personnel controlling that are encountered in the economic practice is defined by the literature, which classifies them into five synthetic groups: the human barrier, the knowledge barrier, the organisational barrier, the information barrier, and the financial barrier, and at the same time deems the barriers related to the human factor of an enterprise to be the most difficult to overcome. This indicates an urgent need to refine instruments improving particular areas of human resources management (Nesterak, 2015, pp. 112-113).

Personnel controlling as one of the main elements of the strategic approach to managing a modern organisation must take into account dynamic changes in the environment, as well as the fact that improper exploitation of non-renewable resources (including human resources) involves many threats to the functioning of enterprises and organisations in all industries. Over the last years, the industry-based economy has been subject to many transformations resulting from the technological progress, which provided a basis for the development of the knowledge-based economy, which in turn, leads to the depreciation of an organisation's human capital if that capital is not improved by means of education, training, and talent development. This necessity stems from the fact that human capital, just like any resource of an organisation, is subject to depreciation. The phenomenon of depreciation is the 'moral wear' caused 
e.g. by the technological progress, which is difficult to keep up with for the current personnel, and the recruitment of new employees having the necessary skills does not meet the demand. The potential of an organisation accumulated in the course of its operation in the form of knowledge and skills, as well as resulting from the work experience of the personnel, is becoming outdated and unattractive in the light of changes occurring in the environment, and especially in competitors. Resources, including human resources, that do not contribute to the products accepted by the market, are becoming hardly useful, as they do not bring profits; thus, changes are required in the organisation and its management (Jamka, 2011, p. 93).

The manner in which personnel controlling is performed in various entities and organisations, i.e. by the owner of a company or by entrusting personnel functions to a specific job, e.g. an HR professional in the financial division, or by establishing a separate personnel controlling unit within the company's organisational structure, is determined especially by factors such as the size of the enterprise, the degree of its development or the industry in which it operates. However, the effectiveness of personnel controlling depends on the manner of management, i.e. setting the objectives and tasks, specifying competences and the number of employees needed to perform particular tasks, appointing a controller or a controlling unit within the organisational structure, determining the resources, making any necessary changes in the organisational structure with regard to the proper positioning of controlling as an organisational unit or determining the reporting lines for particular employees (Pocztowski \& Purgał-Popiela, 2004, p. 189).

Just as any functional controlling, personnel controlling has its own collection of preferable methods and techniques. In the practice of the classic human resources management in 'traditional' Polish enterprises, personnel controlling, having regard to the needs arising from its substance, uses methods enabling, in particular, document analysis and calculations related to human resources, with the use of indicators and checklists. The indicators that are most frequently used in analyses performed in the area of human capital management can be divided into qualitative, quantitative-qualitative, and quantitative (Bernais \& Ingram, 2005, p. 24). The basic measures for human resources in the entire company used as part of indicatorbased analysis are:

- return on investment in human capital - ROIHC. Return on investment in human capital can be treated as the basic measure for the profitability of human resources in the entire enterprise. Its value indicates the 'gains' from funds invested in this area. A negative value means that the employees use more resources to do their work than they generate profits. The value of this indicator is determined as follows: 


$$
\begin{gathered}
\text { return on investment in human capital }= \\
=\frac{\text { Revenue from sales }- \text { operating expenses }- \text { labour costs }}{\text { labour costs }}
\end{gathered}
$$

- value added on human capital (VAHC), which reflects the average profit per FTE and is an effective measure of performance (Fitz-Enz, 2001, p. 48). As it is impossible to state unambiguously what value this indicator should reach, a judgement can be formulated only after it has been compared with the data from other enterprises operating in similar industries and having a similar number of employees (Sierociński, 2002). This value is calculated using the following formula:

$$
\begin{gathered}
\text { value added on human capital }= \\
=\frac{\text { Revenue from sales }- \text { operating expenses }- \text { labour costs }}{\text { FTEs }}
\end{gathered}
$$

Apart from the above-mentioned measures, a traditional economic entity whose functioning is a paradigm of the industrial era uses many specific indicators, which:

- concern directly areas related to employment, i.e. employment structure and level, employee mobility, labour productivity and labour costs, working time organisation and use, work relations evaluated based on individual or group conflicts, employment conditions evaluated based on e.g. the rate of accidents at work and costs borne by the employer e.g. due to accidents, occupational diseases, health protection, OHS benefits;

- reflect the degree of organisational engagement, and in particular the rate of employees satisfied with their job or the percentage of positive assessments of the enterprise as a workplace;

- measure the personnel risk level, whose total level $\left(\mathbf{R}_{\mathbf{p}}\right)$ is calculated as follows:

$$
R_{p}=R_{n} \times R_{s} \times R_{f} \times R_{e} \times R_{r} \times R_{m} \times R_{d}
$$

$\mathrm{R}_{\mathrm{n}}=$ labour demand and supply mismatch risk, $\mathrm{R}_{\mathrm{s}}=$ selection risk, $\mathrm{R}_{\mathrm{f}}=$ role (function) division risk, $R_{e}=$ evaluation risk, $R_{r}=$ employee development investment risk, $\mathrm{R}_{\mathrm{m}}=$ motivation risk, $\mathrm{R}_{\mathrm{d}}=$ de-recruitment (dismissal) risk;

- inform about the effectiveness of human capital management processes; they measure the effectiveness of personnel processes in three categories: costs, efficiency, and rate (time, quantity, quality) (Sierpińska, 2004, p. 197).

A relatively simple organisational technique used commonly in personnel management analyses is a checklist, made up of units concentrating on all important 
aspects of human capital management, such as employment level and structure, the system under which the personnel function is performed, and analysis of the environment of that function.

A checklist complements the indicator-based analysis and although it re-addresses some issues, it remains a useful tool: by concentrating on more general qualitative issues, it draws attention to strategic problems. Thus, a manager of the human capital management team in an enterprise operating based on a simple organisational structure has at their disposal a set of preferable classic management tools, such as economic analysis, including the indicator-based analyses discussed above and checklists, as well as structural analyses, budgeting, and accountancy, including accountancy of knowledge.

The knowledge related to human capital management is particularly important due to the fact that it concerns the most costly area of the operation of private enterprises and public institutions. This means that in most companies, teams managing human capital deal with the largest pool of costs. Costs involved in maintaining and rejuvenating intellectual capital are the largest budget item in knowledge organisations (Heskett et al., 2005, pp. 78-79).

In the $21^{\text {st }}$ century, quantitative methods of personnel controlling in an enterprise are supported by computers. Computer programmes supporting personnel controlling in a company include packages intended for the employment area. Such interactive software based on the internet technology enables current administration and improves the flexibility and economic effectiveness of activities in the area of human resources management (Rostkowski, 2003). However, a drawback is that quantitative methods, being based on data from the past, make it difficult to issue reliable forecasts for the future. This shows that conventional methods, even computer-assisted, are insufficient. In the era of globalisation and technological development, personnel controlling requires support from integrated IT systems enabling the optimum use of the personnel, such as:

- MRP II (Manufacturing Resources Planning);

- ERP (Enterprise Resources Planning);

- HCRM (Human Capital Risk Management).

In order to persuade their subordinates successfully to use advanced technologies, human capital managers must themselves be convinced of the usefulness of IT. They must use them in their work and thus, demonstrate their practical knowledge of the applications of IT systems available on the market, i.e. solutions making it possible to conduct individual sub-processes (functions), e.g. employee selection (optimising the matching of employees to jobs), recruitment, employee assessments, e-learning, handling the training process, talent management, employee development (individual career paths), and motivating employees to improve their e-business competences. 


\section{Conclusion}

Modern enterprises, dealing with growing competition, both national and international, with the rapid development of technology, shortening product life cycles, and changing customer needs and preferences, are increasingly adapting their organisational structure to market requirements, i.e. they are becoming highly complex organisations with considerable development perspectives.

The area of human resources management is considered pivotal both to the meeting of market challenges and to effective management. The measurable value of the owned human resources enables a company to achieve its current and strategic objectives and gives it a chance of further development. Personnel controlling as one of the main elements of the strategic approach to managing a modern organisation must take into account dynamic changes in the environment, as well as the fact that improper exploitation of non-renewable resources (and these are human resources) involves many threats to the functioning of enterprises and organisations in all industries.

The need to implement new IT and ICT systems in a modern enterprise, irrespective of its size or industry, requires synchronising the activities of human capital management teams and IT teams. It is necessary to find the 'golden means of cooperation,' i.e. personnel managers need to learn about and understand issues related to the possibility of employing new technologies, and IT specialists need to understand the needs of the modern personnel management. If the development of appropriate solutions exceeds the cognitive abilities of any of the parties, it is necessary to look for other solutions that will not have an adverse effect on the organisation. Undoubtfully, this is a task for personnel controlling. Human capital is, therefore, capable of generating not only its own value, but also the value of other resources. Thus, while treating human capital as the profit leverage in the economy, it is necessary to continue measurements of the impact of investment in human capital on companies' results, as labour force expenditure represents the largest proportion of the total costs of an enterprise (approx. 40\%), and in public organisations such expenditure is even higher - in education, for instance, it can reach more than $70 \%$. Further research will include measurements of the impact of human capital costs on the achievement of an organisation's objectives. 


\section{References}

Bernais, J., \& Ingram, J. (2005). Controlling personalny i koszty pracy. Katowice: Wydawnictwo Akademii Ekonomicznej im. Karola Adamieckiego w Katowicach.

Bauman, Z. (2000). Globalizacja. Warszawa: Państwowy Instytut Wydawniczy.

Champlin, D.P., \& Knoedler, J.T. (2004). J.M. Clark and the Economics of Responsibility. Journal of Economic Issues, 38(2), 545-552. Retrieved from: https://www.jstor. org/stable/4228042 (11.10.2019).

Czapiński, J. (2008), Kapitał ludzki i kapitał społeczny a dobrobyt materialny. Polski paradoks. Zarządzanie Publiczne, 2(4), 5-28.

Encyklopedia PWN. Retrieved form: www.encyklopedia.pwn.pl/haslo/globalizacja;3905881.html (11.10.2019).

Encyklopedia PWN. Retrieved from: www.encyklopedia.pwn.pl/haslo/rozwoj-zrownowazony (11.10.2019).

Heskett, J.L., Eral Sasser, W. Jr., \& Schlesinge, L. (2003). The Value Profit Chain. New York: The Free Press, 78-79. After: Bochniarz, P., \& Gugała, K. (2005). Budowanie i pomiar kapitału ludzkiego $w$ firmie. Warszawa: Poltext.

Ignaciuk, E. (2000). Controlling personalny w zarządzaniu przedsiębiorstwem. Controlling i Rachunkowość Zarzq̨dcza, 8, 23-26.

Jamka, B. (2011). Czynnik ludzki we wspótczesnym przedsiębiorstwie: zasób czy kapitał? Warszawa: Wolters Kluwer business.

Konstytucja Rzeczypospolitej Polskiej, art. 5; tekst uchwalony w dniu 2 kwietnia 1997 r. przez Zgromadzenie Narodowe; Dz. U. 1997, Nr 78, poz.483. Retrieved from: www. sejmgov.pl/prawo/konst/polski/kon1.htm (15.10.2019).

McLuhan, M. (1975). Wybór pism. Przekaźniki, czyli przedłużenie człowieka. Galaktyka Gutenberga. Poza punktem zbiegu. Warszawa: Wydawnictwa Artystyczne i Filmowe.

Nesterak, J. (2015). Controlling zarządczy, projektowanie i wdrażanie. Warszawa: Oficyna a Wolters Kluwer business.

Nowak, M. (2008). Controlling personalny w przedsiębiorstwie. Kraków: Oficyna Wydawnicza.

Lisiecka, K., \& Burka, I. (2015). Źródła powstawania marnotrawstwa w organizacjach ciepłowniczych na przykładzie usługowych przedsiębiorstw ciepłowniczych. Studia Ekonomiczne, Zeszyty Naukowe Uniwersytetu Ekonomicznego w Katowicach, 233, 75-92.

Listwan, T. (Ed.) (2010). Zarzq̨dzanie kadrami. Warszawa: Wydawnictwo C.H. Beck.

Pocztowski, A., \& Purgał-Popiela, J. (2004). Controlling personalny. In: M. Sierpińska (Ed.), Controlling funkcyjny w przedsiębiorstwie. Kraków: Oficyna Ekonomiczna, 179-207. Powszechna Deklaracja Praw Człowieka. UNICWARSAW Ośrodek Informacji ONZ w Warszawie. Retrieved from: www.unic.un.org.pl/dokumenty/deklaracja.php (12.10.2019). 
Robertson, G.R. (1992). Globalization: Social Theory and Global Culture. London: SAGE Books.

Rostkowski, T. (2003). Narzędzia Inter-, intra- i ekstranetowe w realizacji funkcji ZZL. In: M. Rybak (Ed.), Kapitał ludzki a konkurencyjność przedsiębiorstw. Warszawa: Poltext.

Sierpińska, M. (Ed.) (2004). Controlling funkcyjny w przedsiębiorstwie. Kraków: Oficyna Ekonomiczna.

Smolarek, M. (2016). Wzrost znaczenia technologii informatycznych w zarządzaniu kapitałem ludzkim w organizacji. In: M. Smolarek (Ed.), Technologie informatyczne w zarzadzaniu kapitatem ludzkim w organizacji. Katowice: Wydawnictwo Uniwersytetu Ekonomicznego w Katowicach.

Struge, G. (2018), Migration Statistics, House of Commons, Briefing Paper, No. SN0677, 24 August 2018, House of Commons Library, Office for National Statistics. Retrieved from: https://www.ons.gov.uk (26.8.2018).

Ustawa z dnia 27 kwietnia 2001 roku Prawo ochrony środowiska (Dz. U. z 2019, poz. 1396).

\section{Michal Zubek}

$\mathrm{PhD}$ in Economic Sciences in the field of management sciences, the Institute of Human Capital, Collegium of Business Administration, SGH Warsaw School of Economics. His main scientific interests include the use of controlling tools in enterprises' activity, especially methods of managing, personnel controlling, personnel management, human resource analytics and financing of business entities. He has practical experience as a manager both in the public and private sector.

e-mail address: mzubek@sgh.waw.pl

ORCID: 0000-0002-9280-8503 